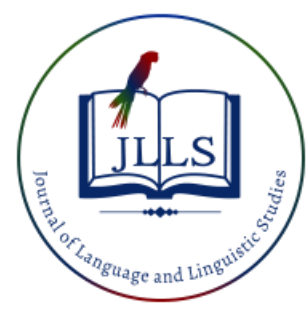

Available online at www.jlls.org

JOURNAL OF LANGUAGE AND LINGUISTIC STUDIES

ISSN: 1305-578X

Journal of Language and Linguistic Studies, 16(4), 2040-2058; 2020

\title{
Examining the effect of explicit instruction on vocabulary learning and on receptive-productive gap: An experimental study
}

\author{
Infanta Vincy R al i \\ ${ }^{a}$ CHRIST (Deemed to be University), Bengaluru, India

\section{APA Citation:} \\ Vincy, I. R. (2020). Examining the effect of explicit instruction on vocabulary learning and on receptive-productive gap: An experimental \\ study. Journal of Language and Linguistic Studies, 16(4), 2040-2058. \\ Submission Date: 21/7/2020 \\ Acceptance Date:24/09/2020
}

\begin{abstract}
This research study emphasized the importance of explicit instruction and repeated exposure to the target vocabulary for effective reception and production of new words among the second language learners of English. The purpose of the study was to examine the efficacy of the researcher- created supplementary for the prescribed set of vocabulary in the English language textbook. The study aimed to find out the amount of influence the explicit instruction and repeated exposure to the target vocabulary had on the nature of the receptive- productive gap. A total of sixty-two sixth grade students from a Government school in Tamil Nadu, India, participated in the experimental study which was conducted over a period of three months. The results of the study showed that the explicit instruction and repeated exposure to the target vocabulary had a significant amount of influence on vocabulary knowledge when compared to the conventional way of vocabulary instruction. In the conventional mode of vocabulary instruction, reception of vocabulary was found to have an average of $8 \%$ influence on the production knowledge, whereas in the case of the experimental group, it amounted up to $72 \%$. This analysis showed that through explicit instruction and repeated exposure to the target vocabulary the receptive- productive gap is significantly reduced.
\end{abstract}

(C) 2020 JLLS and the Authors - Published by JLLS.

Keywords: explicit instruction; repeated exposure; receptive vocabulary; productive vocabulary; receptiveproductive gap

\section{Introduction}

The process of learning English as a second language primarily consists of learning the two elements of language, namely the grammar and vocabulary, and developing the listening, speaking, reading and writing skills. "Without grammar very little can be conveyed, without vocabulary nothing can be conveyed" is one of the significant comments on the inevitability of vocabulary by the linguist David Wilkins (cited in Thornbury, 2006, p. 13). Dubin, Olshtain and McCarthy (cited in O'Dell, 1997) voiced the dominance of syntax and functions in the course books in the 1980's at the expense of lexical development. The argument that the syllabus theorists put forward is that lexis should be given much more focus in any coursework. They do not advocate the omission of grammar. Grammar and

\footnotetext{
${ }^{1}$ Corresponding author. Tel.:

E-mail address: infant.r@ res.christuniversity.in
} 
vocabulary should not be viewed as a dichotomy; "one must conceptualize them as partners in synergy with no discrete boundary" (Schmitt, 2000, p. 14).

In the Tamil Nadu (India) Curriculum Framework's Draft Syllabus (SCERT, 2017), the objectives in specific to the vocabulary development of the sixth standard students are to facilitate the growth of passive vocabulary knowledge and to encourage the usage of active vocabulary in everyday contexts and classroom situations. However, the vocabulary aspects of the English language textbook were found to be insufficient to foster reception and production of vocabulary among the regional medium students in a selected sample in Tamil Nadu. In fact, the textbook material used helped in only 'partial reception' of the target words among the Tamil medium students. The researcher identified the gap between the reception and production of vocabulary and realized the need to create a supplementary for the new syllabus English textbook and examine its effectiveness in the selected context, in terms of the reception and production of vocabulary.

\subsection{Relevance of the study}

The Tamil Nadu Curriculum Framework's Draft Syllabus (SCERT, 2017), published by the State Council of Educational Research and Training, states that "Learners at the intermediate language level begin to understand and communicate academic vocabulary and varied grammatical forms," (p. 42). In addition, the objectives of vocabulary teaching in standard VI according to the draft syllabus are to gather knowledge of passive vocabulary and to aptly use the active vocabulary in everyday contexts, in speech or writing. However, the vocabulary components in the textbook were found to be limited in the previous research studies and the students remained only in the receptive phase of vocabulary acquisition when analysed with Henriksen's three dimensions of vocabulary development (1999) (see section 3). The researcher believes that this supplementary for vocabulary would help the students to move along the continuum towards the production phase in order to achieve the proposed objectives of the curriculum. This supplementary is based on the vocabulary acquisition theories and the findings of the available literature on various aspects of vocabulary acquisition. The researcher has attempted to organize the content of the supplementary in the simplest form having in mind the functionality of supplementary to the target age group.

\subsection{The aim of the study}

The purpose of the study was to investigate the effect of explicit teaching (first language equivalent, contextual introduction and pictorial representation) and repeated exposure to the target vocabulary on the receptive and productive vocabulary knowledge development. The study also aimed to analyse the impact of explicit instruction and repeated exposure on the nature of the receptive-productive gap. The influence of these factors on the vocabulary development of the learners will be measured in terms of both the reception and production of vocabulary. The study also aimed to equip the students with the learning strategies for learning and retaining new vocabulary and for further development of vocabulary knowledge which would lead to free production ability through the use of the supplementary.

\section{Literature review}

\subsection{Reception and production of vocabulary}

This research aims to reduce the gap between the reception and production of vocabulary and the literature shows that they lie on a continuum rather than assuming that they are mutually exclusive. According to Schmitt (2000), vocabulary acquisition is of incremental nature as "words are not 
instantaneously acquired" and "they are gradually learned over a period of time from numerous exposures" (p. 4). The reception and production of vocabulary are basically the different degrees of knowing a word. Melka (1997) used the term 'familiarity' in place of degrees of knowing a word which are "imperceptible and infinite" (p. 85). The degrees of familiarity of a word begins from as basic as partial recognition of the form of the word. Partial recognition of the word stored in the learner's mental lexicon leads neither to reception nor production of the word. Receptive vocabulary is the ability to perceive "the form of a word while listening or reading" (Nation, 2001, p. 26) and to retrieve its definition. The "productive vocabulary is the ability to express a meaning through speaking or writing and retrieving and producing the appropriate spoken or written form" (Nation, 2001, p. 26). The amount of information required to receive a word is lesser than the amount of information required for an individual to produce a word.

The relationship between these two aspects of vocabulary may seem is complex to define and to relate them with each other. "A crucial factor would be to establish at what point familiarity is such that one could say that knowledge is no longer receptive, but is productive" (Melka, 1997, p. 86). Melka (1997, p. 89) attempted to break down the distance between reception and production into four intermediary phases such as imitation/ reproduction without assimilation, comprehension, reproduction with assimilation and production. It is observed that the "passage from R (reception of vocabulary) and P (production of vocabulary) is not clear and neat" (Melka, 1997, p. 100) and that production began even before complete reception of the word in a few cases. This reflected the fact that they are "not watertight compartments" (Melka, 1997, p. 100) and they overlap and interact with each other. The argument that the two notions belong to two separate systems should be rejected "in favor of visualizing the distance between $\mathrm{R}$ and $\mathrm{P}$ as a line, a continuum of knowledge" (Melka, 1997, p. 100). The researcher's assumption here is that the gap between the reception and production of vocabulary can hence be reduced by strengthening the reception of the word or in other words increase the range of the reception of the target words.

\subsection{Modes of vocabulary instruction and learning}

The three modes of vocabulary instruction differ in the range of explicitness of vocabulary in the teaching of second language. In implicit mode of vocabulary instruction the assumption is that vocabulary is learnt subconsciously and so the teacher need not intend to instruct the target vocabulary directly. The intention to introduce the new target words to the learners is slightly high in the case of embedded mode of vocabulary instruction. The range of explicitness in the teaching of vocabulary in the second language learners of English is at the maximum in the explicit mode of vocabulary instruction. However, the English language curriculum usually does not specify an instruction mode that needs to be followed in teaching the target vocabulary in the textbook provided. Specification of an instruction mode also requires the lessons to be planned and designed in a certain way which is in alignment with the prescribed mode to teach vocabulary.

Schmitt (2000) suggested that there are two approaches to vocabulary acquisition. The first approach is where the attention is drawn towards the information to be acquired and is called 'explicit learning'. The second approach is called the 'incidental learning' where language is used for communicative purposes and does not focus exclusively on new words in the text. The effectiveness of explicit instruction is supported by the findings from the psychological studies on the 'depth of processing hypothesis.' The study stated that the range of engagement with a particular word, that is the amount of information, association and mental images established with the target word, is directly proportional to the ability to retrieve the word for later use. The availability of a supplementary exclusively on the target vocabulary with practice sections enables the students to explicitly gain new vocabulary in an effortless 
way. One of the primary aims of the study is to examine whether these modes of vocabulary teaching and learning gives better results in the vocabulary knowledge development along the continuum.

\subsection{Psychological conditions for vocabulary learning}

Psychological conditions play a major role in vocabulary learning. Understanding those conditions has helped in framing the second language vocabulary acquisition theories, methodologies and strategies. Stallman (1991) found that "none of several methods of drawing attention to words" (underlining or bold facing) "had any impact on word learning" and that it had "negative impact on comprehension" (cited in Nagy, 1997, p. 81). Nation (2001) identified three important psychological processes to be involved in efficient learning of vocabulary. It includes noticing the word in written or spoken form influenced by motivation and interest, retrieving the word either receptively or productively and generating the word in another form or context. Repeated retrievals help the learner from using the derivatives, inflected forms of the word, different grammatical forms, to generating the metaphorical extensions of the word form. The supplementary is designed in such a way that each of the target vocabulary is noticed, retrieved and generated.

\subsection{Frequency and repetition}

Nation (2001) brought out a very important distinction between the high frequency words and low frequency words "on the basis of frequency, coverage and quantity of words" (p. 21), and awareness of this distinction is important both to teachers and learners of English so that it is ensured that the highfrequency words are given more importance in teaching and learning and that it is well known. Nation (2001) stressed on the importance of repetition as an essential factor in the learning of vocabulary. Nation (2001) stated that "vocabulary items must not only be known, they must be known well so that they can be fluently accessed" (p. 74) and that a single meeting with a word would not suffice for gaining the required information for usage. "Embedding words in rich, instructive contexts alone did not contribute to better opportunities for vocabulary learning. It needed to be coupled with noticing and frequent meetings over a distributed period to improve vocabulary development" (Joe, 2010, p. 134). Melka (1997, p. 86) put forward the same idea that "after the first apprehension certain traces remain in the brain but the traces are quite insufficient to be actualized without repeated apprehension of the same material."

Repetition should be spaced in increasing larger intervals rather than massed together over a particular time span (Dempster, 1987; cited in Nation, 2001). Secondly, Nation (2001) shows how most forgetting occurs right after learning the new vocabulary and hence repetition should be facilitated at the earliest. Nation (2001) interestingly pointed out that the favorable time for repetition is when "the learner has forgotten enough to feel that the repetition is worthwhile attending to and yet not forgotten too much so that there is still a good chance of recalling" (p. 77), which thereby strengthened the formmeaning connection. Thirdly, it is stated that repetition here does not refer to the mere exposure to the form and meaning of the word, but refers to the exposure of the learner to the repeated process of retrieval as it is "more similar to the performance required during normal use" (Nation, 2001, p. 79). Hart (2017, as cited in Liang, 2019) also emphasizes on repetition for improving productive vocabulary while saying that understanding, context and familiarity are the three key areas that need attention. Finally, the studies suggested that a word has to be repeated between five to seven times contextually in various discourses in the coursework to facilitate learning for most of the learners. 


\section{Theoretical framework}

Vocabulary learning is not an instantaneous process but involves various degrees of understanding. The acquisition of a new word as a process begins from recognition of the form of the word in the target language, phonological awareness and then moves to vague understanding of the meaning of the word. This partial knowledge of the word gradually moves along the continuum to precise comprehension and this is precisely called as the knowledge continuum (I) (Henriksen, 1999). Schmitt (2000) found evidence for these degrees of knowledge in a study conducted at the University level L2 learners. That is, knowledge of any lexical aspect moved along a continuum from zero to partial to precise, rather than being known versus unknown.

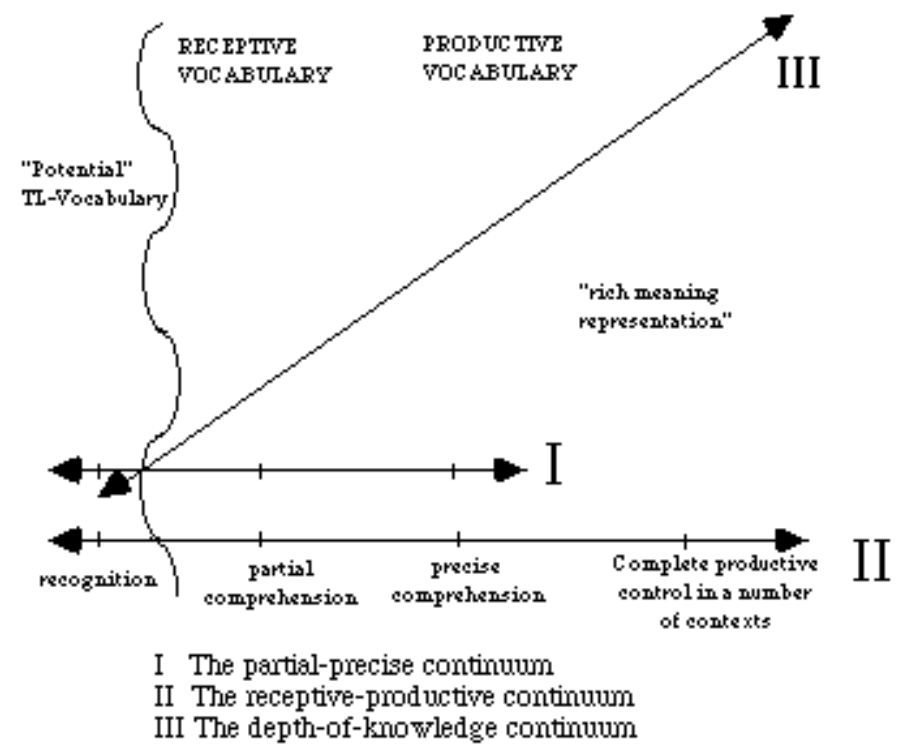

Figure 1. Henriksen's three dimensions of vocabulary development (waring, 1999)

The second dimension (II) involves the knowledge of the different aspects of knowing a word as defined by Richards (1976), Nation (2001), Schmitt (2000), Meara (1997) and Thornbury (2006). This dimension refers to the development of the semantic network which means awareness of the morphologic, syntactic, and collocation profiles of the words. It defines the ability of the learner to establish connections with the related syntagmatic and paradigmatic lexical items. While learning the different items from similar lexical sets, the knowledge of first dimension simultaneously moves towards precise comprehension. Progression of a learner's vocabulary knowledge results in the ability of the learner to store and retrieve the words. The third dimension (III), the control continuum, refers to the control over the learnt vocabulary in terms of comprehension and production of the words in the required contexts. The range of control over a particular word in terms of retention and accessibility is dependent on the range of declarative knowledge of that lexical item. Thus, all three dimensions of vocabulary are strongly interrelated. The knowledge of a given word grows in relationship to other words and their relationships with others.

Vocabulary knowledge development is not an "all-or nothing affair" (Meara, 1982, cited in Palmberg, 1987, p. 202) as it progresses over a continuum from unknown to known while the paradigmatic and syntagmatic features of the words are learnt simultaneously. The better a learner knew a word, further he/ she moved along the continuum. 


\section{Development of the supplementary}

The supplementary was designed to enrich the students in the process of the reception of new vocabulary. It emphasized on repeated exposure to the target words at regular intervals. The explicit instruction and repeated exposure fostered the development of the received vocabulary to the controlled production stage.

The supplementary was created for the Term 1 English textbook of Standard VI (the 2017 revised syllabus). All the target words under every unit were taken into consideration. Every unit had an average of 15 target words and the below listed components were included for each and every word in the supplementary(see Appendix B \& C). The timeline for the completion of the units was mentioned for every unit in terms of weeks. More detailed timeline was drafted along with the English teacher of the target class for this study. Every unit begins with a worksheet which is a revision of the words received in the previous week and ends with a test of the newly acquired target words. The scores of these tests were tracked over weeks to trace the vocabulary development right after experimentation and also to examine the retention of the target vocabulary.

The Components of the Supplementary (see Appendix A)

1. Contextual introduction of the target vocabulary

2. Focus on the form

3. Pictorial representation of the meaning of the target word

4. Meaning of the word in the first language

5. Most frequent derivatives of the word

6. Pronunciation of the word

7. Creating a means for emotional association with the word meaning

8. Singular and plural forms in case of nouns

9. Awareness about the possible confusions with the existing knowledge or similar words (if applicable)

10. Unlearning the wrong usage of the target word

\section{The main study}

The experimental study was conducted with a controlled and an experimental group. The researcher created a module which was piloted and was validated by three subject experts. The researcher used standardized vocabulary tests such as the Vocabulary Knowledge Scale (VKS) test (Wesche and Paribkht, 1996) and Nation's Productive Levels Test (Laufer \& Nation, 1999) to gauge the reception and production of vocabulary.

The main experimental study was conducted over a period of 11 weeks in total, with an average of four hours per week. The participants of the main study were sixth standard students from two different sections (a grade class is divided into two or more sections when the strength of the class is beyond 40) where one was the controlled group (sixth grade section ' $\mathrm{D}$ ') and the other was the experimental group (sixth grade section ' $\mathrm{C}$ '). These students were basic users of English language and they were at A1 level of the CEFR global proficiency scale. The total number of participants in the main study from both the experimental and controlled groups was sixty- two. 
The schools primarily divide the students into different sections in a way that there is a mix of the high, average and low scoring students. Apart from this assumption, a pretest was conducted in both the classes in order to equate the participant groups. The target words tested in the study were the words from the fifth standard term III English textbook. The students' vocabulary knowledge of the target words were scored on the basis of their reception and production abilities using the Vocabulary Knowledge Scale (VKS) test (Wesche and Paribkht, 1996) and Nation's Productive Levels Test (Laufer \& Nation, 1999). Independent samples $t$ - test was conducted on the overall performance scores of the students from the two sections. The scores were analyzed using SPSS and the results are tabulated below.

Table 1. Pretest -independent samples t-test

\begin{tabular}{ccccccccc}
\hline & Group & $\mathrm{N}$ & Mean & $\begin{array}{c}\text { Std. } \\
\text { Deviation }\end{array}$ & $\begin{array}{c}\text { Std. Error } \\
\text { Mean }\end{array}$ & $T$ & Df & Sig \\
\hline $\begin{array}{c}\text { Pre- test } \\
\text { Reception }\end{array}$ & Control & 31 & 10.7097 & 9.66848 & 1.73651 & -.765 & 60 & .595 \\
& Exp. & 31 & 12.4516 & 8.21315 & 1.47513 & -.765 & 58.471 \\
$\begin{array}{c}\text { Pre- test } \\
\text { Production }\end{array}$ & Control & 31 & 4.2903 & 6.64928 & 1.19425 & -.284 & 60 & .694 \\
& Exp. & 31 & 4.7419 & 5.82505 & 1.04621 & -.284 & 58.979 \\
\hline
\end{tabular}

From Table 1 , it is evident that $t$ value is not significant in both Reception ( $t=-0.765, \mathrm{p}>0.05)$ and Production $(t=-0.284, \mathrm{p}>0.05)$ of vocabulary based on the pre- test. Through this analysis it is proved that there are no significant differences in the reception and production pre- test mean scores of the Experimental Group (EG) and Control Group (CG). It is hence understood that the two sets of participants of the main study are equated in terms of their vocabulary knowledge.

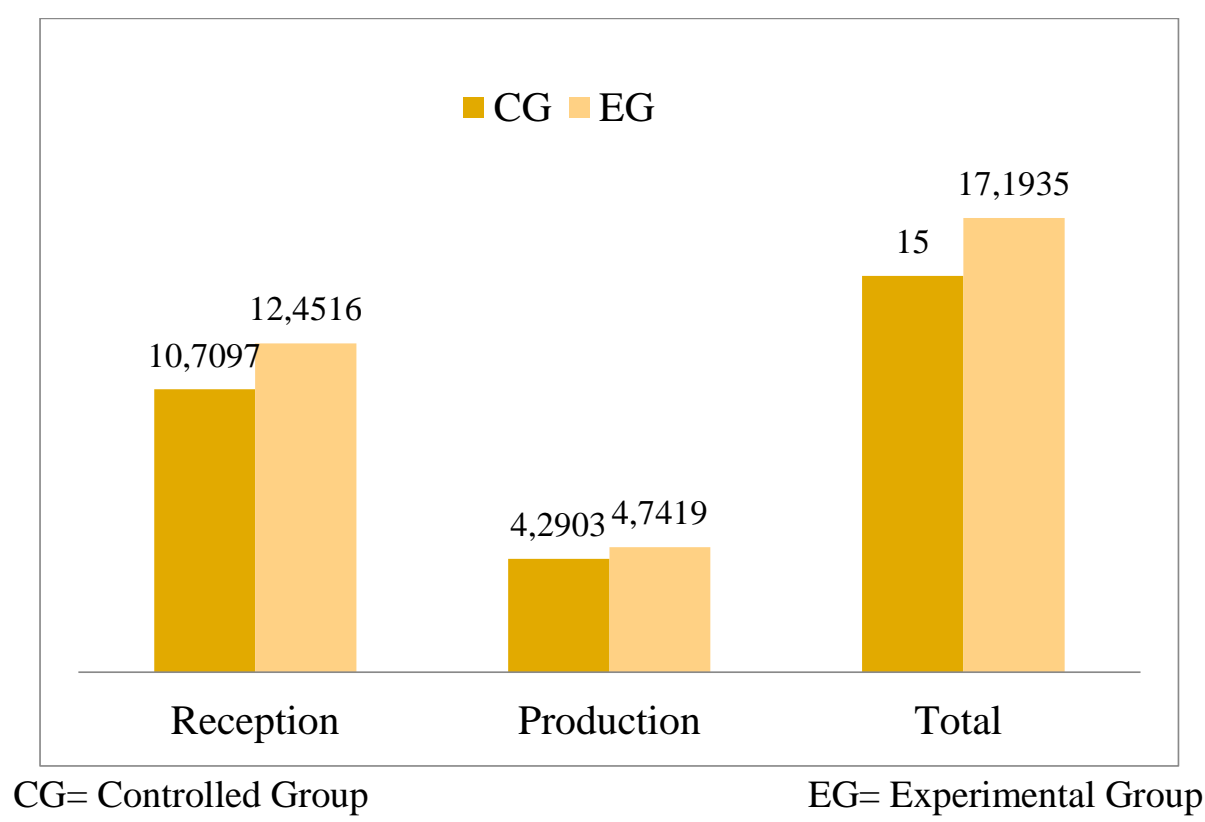

Figure 2. Comparison of reception, production and total based on pre-test

The students encountered an average of four target words on a day in a particular part of the lesson planned for the day (see appendix B). The newly learnt words were revised the very next day after the encounter. The revision of the words here means the process of recall and re-production and not mere 
exposure to the form and the meaning of the words. The task of production of the words at the sight of the pictures was the first stage and this was followed by the task of the production of the words in hearing a context. A similar procedure was followed for all the target words in the Term I. All the lessons of the Term 1 were completed by the $10^{\text {th }}$ week of the study. The researcher then conducted the post test in both classes. The tests were evaluated using the prescribed scoring pattern that includes standardized vocabulary tests namely the Vocabulary Knowledge Scale (VKS) test (Wesche and Paribkht, 1996) and Nation's Productive Levels Test (Laufer \& Nation, 1999) (see Table 2).

Table 2. Scoring pattern of the reception and production tests

\begin{tabular}{cccc}
\hline $\begin{array}{c}\text { Knowledge } \\
\text { Levels }\end{array}$ & The Standardized test design used & Description of the Levels & Scores \\
\hline Level 1 & VKS & Recognition of the form (R) & 1 \\
Level 2 & VKS & Recognition of the meaning (R) & 1 \\
Level 3 & VKS & Selection of the right meaning (R) & 1 \\
Level 4 & VKS & Providing the equivalent L1 word (R) & 1 \\
Level 5 & Nation's Productive Levels Test & Controlled production (P) & 1 \\
Level 6 & VKS & Free production (P) & 1 \\
\hline
\end{tabular}

\section{Results and Discussion}

In order to find if there was a significant difference in the mean scores of reception and production knowledge between the controlled group and experimental group post the intervention, an independent samples $t$ - test was performed and the results are tabulated below in Table 3 .

Table 3. Posttest- independent samples t-test

\begin{tabular}{ccccccccc}
\hline & Groups & N & Mean & $\begin{array}{c}\text { Std. } \\
\text { Deviation }\end{array}$ & $\begin{array}{c}\text { Std. Error } \\
\text { Mean }\end{array}$ & $t$ & Df & Sig. \\
\hline $\begin{array}{c}\text { Posttest } \\
\text { Reception }\end{array}$ & Control & 31 & 9.4516 & 5.89259 & 1.05834 & -7.585 & 60 & .000 \\
& Exp. & 31 & 47.0645 & 26.97398 & 4.84467 & -7.585 & 32.857 & \\
$\begin{array}{c}\text { Posttest } \\
\text { Production }\end{array}$ & Control & 31 & 6.7742 & 11.26265 & 2.02283 & -6.097 & 60 & .000 \\
& Exp. & 31 & 35.7419 & 23.93737 & 4.29928 & -6.097 & 42.662 & \\
& & & & & & & & \\
\hline
\end{tabular}

From Table 3, it was evident that $t$ value was significant in both reception $(t=-7.585, \mathrm{p}<0.05)$, and production $(t=-6.097, \mathrm{p}<0.05)$ of vocabulary knowledge $(t=-7.289, \mathrm{p}<0.05)$ based on the Posttest. 


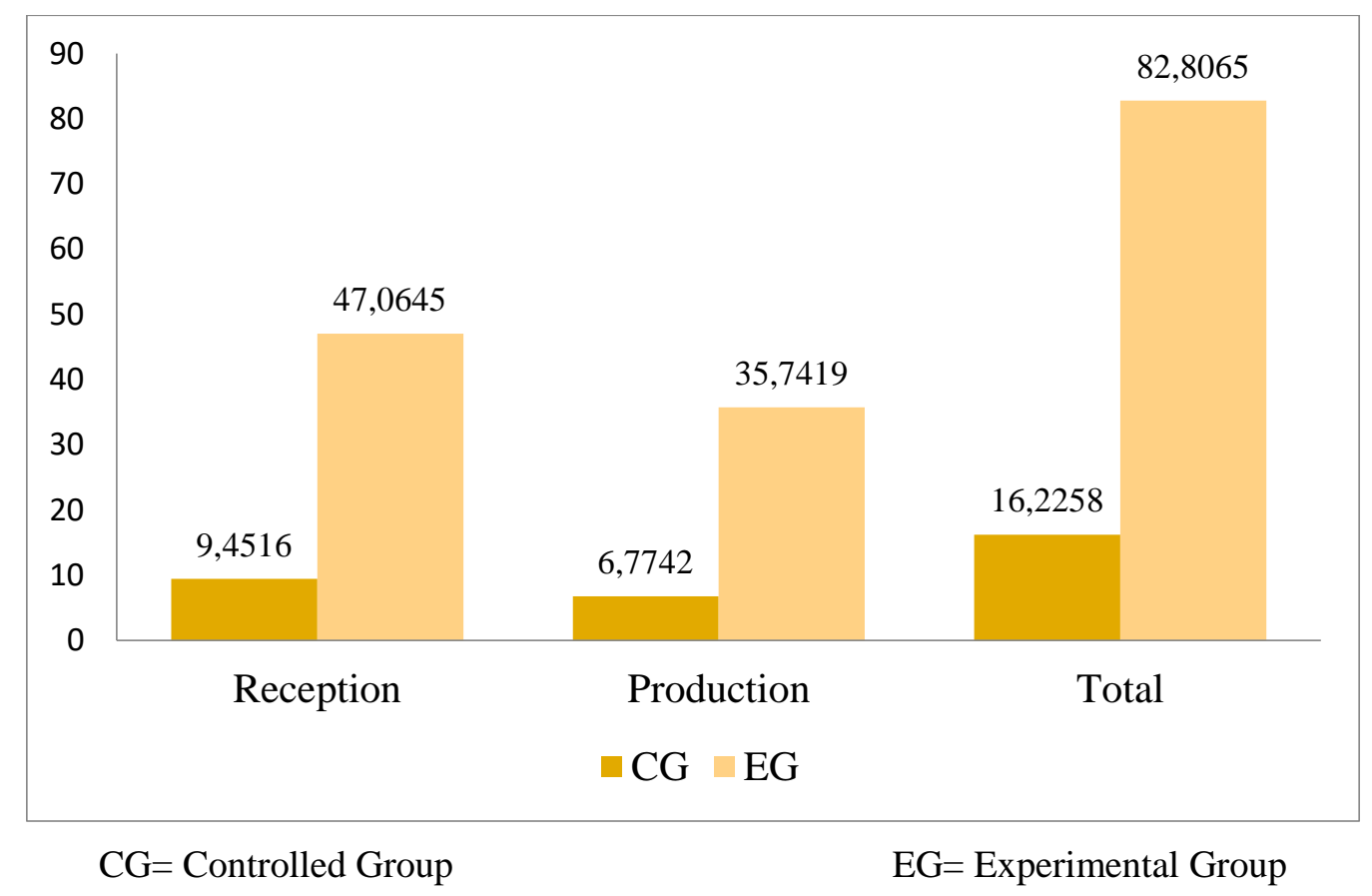

Figure 3. Comparison of reception, production and total based on post-test

The use of the researcher-created supplementary in the teaching of target vocabulary resulted in a significant increase in the scores of both reception and production of vocabulary in the selected context. The total score of the participants from the experimental group demonstrated a significant increase in vocabulary knowledge when compared to the controlled group participants for the same set of target words.

The researcher further conducted the correlation and regression analyses to understand the nature of relationship between the two aspects of vocabulary: reception and production. The literature shows that these two aspects lie on a continuum. Firstly, correlation analysis was done between the reception and production scores across all four sets of variables to trace the nature of relation.

Table 4. Variable-wise Pearson correlation and sig. values

\begin{tabular}{ccc}
\hline Variables & Pearson's Correlation & Sig. \\
\hline $\begin{array}{c}\text { CG Pretest Reception } \\
\&\end{array}$ & .326 & .073 \\
CG Pretest Production & & \\
$\begin{array}{c}\text { CG Post-test Reception } \\
\&\end{array}$ & .191 & .302 \\
CG Posttest Production & & \\
EG Pretest Reception \\
$\&$ \\
EG Pretest Production \\
EG Post-test Reception \\
$\&$ \\
EG Post-test Production
\end{tabular}

On Table 4 it is seen that the reception and production of vocabulary are positively correlated across all four sets of variables. However, it is evident that only in the case of experimental group, in the post intervention, the reception and production of vocabulary are significantly correlated at 0.01 level 
$(\mathrm{p}<0.01)$. Through this analysis it is proved that there is a significant difference in the relationship between reception and production of vocabulary due to the use of the vocabulary supplementary (explicit instruction and repeated exposure to the target vocabulary).

Now that the data is proved to be positively correlated across all four sets of variables, the researcher went ahead and conducted a regression analysis to determine the strength of the correlation among the same sets of variables.

Table 5. Variable- wise R-square, constant, independent variable and beta values

\begin{tabular}{|c|c|c|c|c|}
\hline $\begin{array}{c}\text { Variables } \\
\text { (Independent Variable- IV; } \\
\text { Dependent Variable- DV) }\end{array}$ & R Square & Constant & B & Beta \\
\hline $\begin{array}{c}\text { CG Pretest Reception (IV) } \\
\&\end{array}$ & .107 & 1.886 & .225 & .326 \\
CG Pretest Production (DV) & & & & .191 \\
\hline $\begin{array}{c}\text { CG Post-test Reception( IV) } \\
\&\end{array}$ & .037 & 3.316 & .366 & \\
$\begin{array}{c}\text { CG Posttest Production (DV) } \\
\text { EG Pretest Reception (IV) }\end{array}$ & .103 & 1.902 & .228 & \\
\hline $\begin{array}{c}\text { EG Pretest Production (DV) } \\
\text { EG Post-test Reception(IV) } \\
\&\end{array}$ & .725 & & & .822 \\
EG Posttest Production (DV) & & & & \\
\hline
\end{tabular}

From Table 5, it is evident that the reception of vocabulary has positive influence on the production of vocabulary across all four sets of variables. However, it is noticed that there is a significant influence of reception on the production of the target vocabulary only in the case of the experimental posttest. This means that $72 \%$ of the production can be explained by the reception of vocabulary. Through this analysis it is proved that the strength of the influence of the reception on the production of vocabulary is increased with explicit instruction of vocabulary and repeated exposure to the target vocabulary (the use of supplementary for vocabulary instruction).

For the visual understanding of the change in the nature of the relationship between the reception and production of vocabulary, the individual scores of the participants in the posttest from both the controlled and the experimental groups are traced over the line graphs in Figure 4 and Figure 5. The gap between the reception and production scores of the target vocabulary in the case of the controlled group is wide in Figure 4. However, in Figure 5, the reception and production lines are evidently seen to be almost merging with each other. 


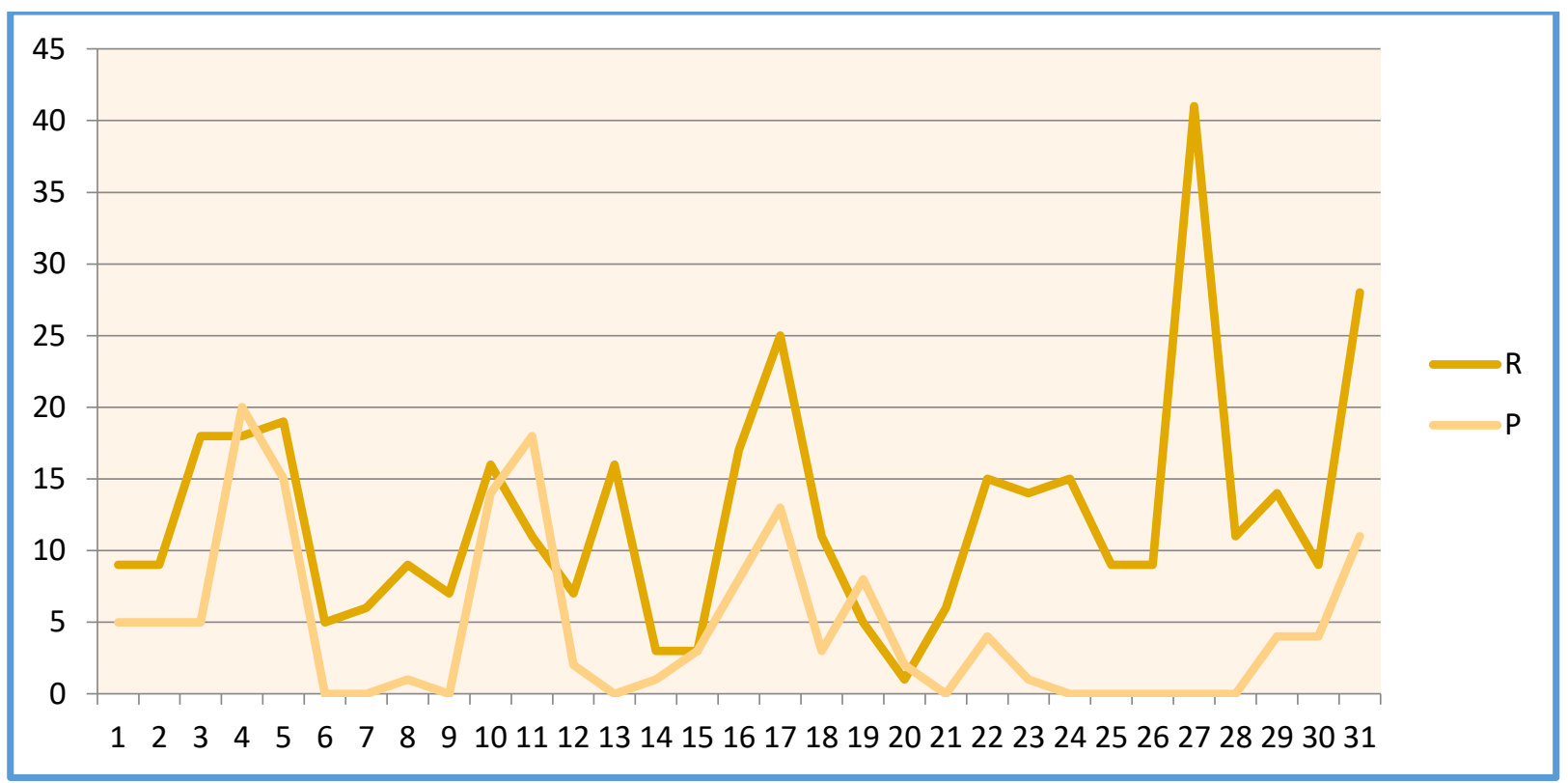

Figure 4. Reception and production scores of the controlled group based on post-test

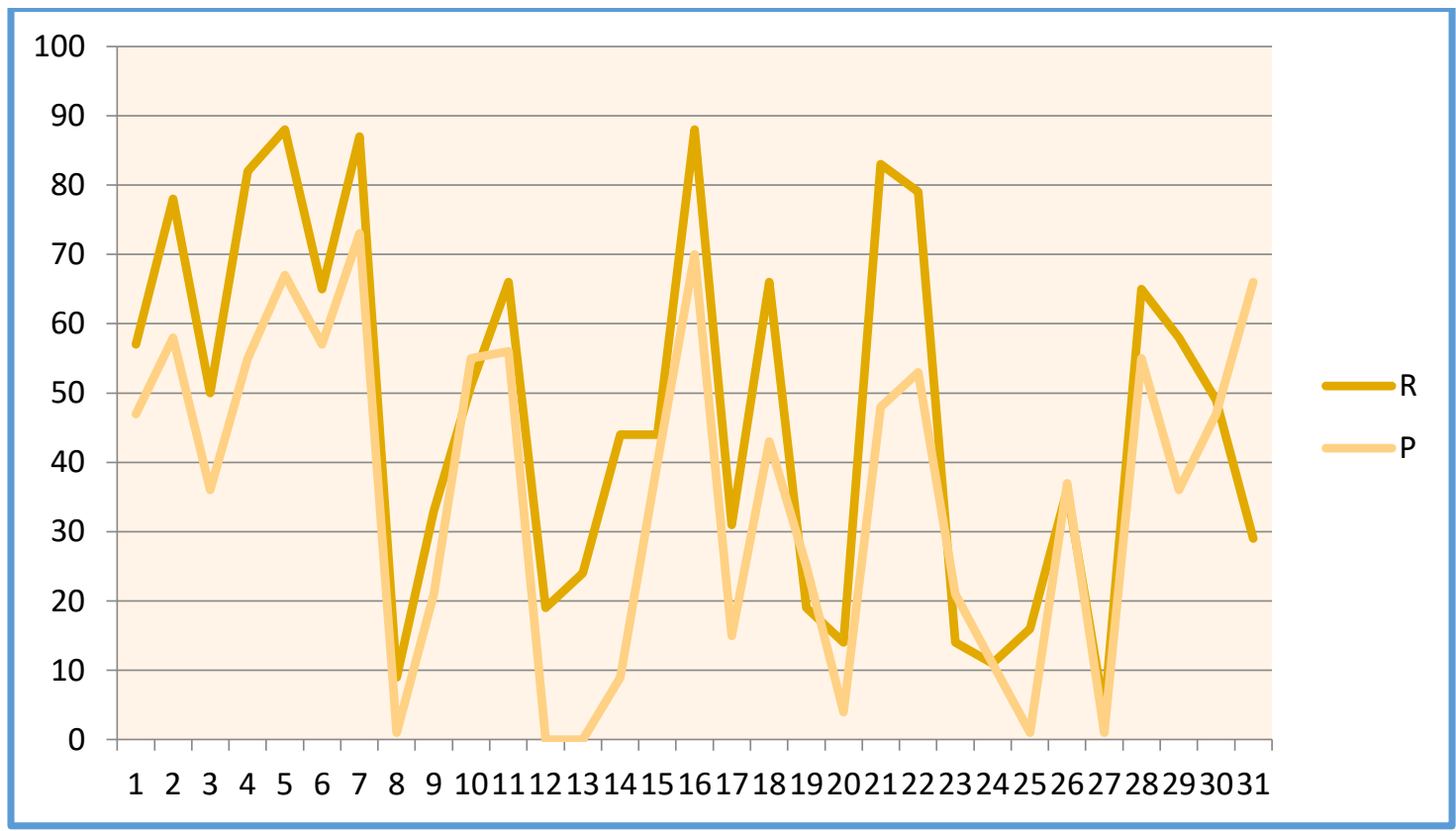

Figure 5. Reception and production scores of the experimental group based on post-test

The results of the data showed that explicit instruction and repeated exposure to the target vocabulary had a great amount of influence on the scores of the receptive and productive vocabulary knowledge when compared to the conventional way of vocabulary instruction. To ensure that the students from both the experimental and the controlled groups had similar vocabulary knowledge, an independent samples $t$ - test was conducted with the pretest scores and the results showed that the samples were equated. Though the pretests and the post-tests were designed in the same testing pattern, the target words tested were from the fifth standard Term III and sixth standard Term I textbooks respectively. In order to make sure that the nature of the words in terms of frequency, cognates or grammar, had no major influence on the participants' vocabulary knowledge, paired samples $t$ - test was conducted individually for both the controlled and the experimental groups of participants. The scores from the pretests and the post-tests were tabulated and it was found that there was no significant difference in the vocabulary knowledge 
level of the participants from the controlled group between the two sets of target words. On the other hand, the participants from the experimental group showed a significant difference in the paired samples $t$-test. This analysis is crucial to state that explicit instruction and repeated exposure to the target words had a significant influence on the reception and production knowledge of vocabulary, notwithstanding the nature of the target words or the vocabulary knowledge level of learners.

Another objective was to find the amount of influence the supplementary had on the nature of the receptive- productive gap. In the correlation analysis, it was confirmed that the reception of vocabulary was positively correlated with the production of vocabulary across the pretest and posttest of the experimental and the control groups. However, the Pearson's correlation showed that only the post-test reception and production of the experimental group was significantly positively correlated. The regression analysis of the obtained data was important to gauge the amount of influence the explicit instruction and repeated exposure to target vocabulary had on the nature of relationship between the reception and production of vocabulary. An interesting finding from this analysis is that in the conventional modes of vocabulary instruction, reception of vocabulary is found to have an average of $8 \%$ influence on the production knowledge, whereas in the case of the experimental group, the reception and production scores post the intervention amounted up to $72 \%$. This analysis showed that through explicit instruction and repeated exposure to the target vocabulary the receptive- productive gap is significantly reduced.

\section{Conclusions}

The knowledge of vocabulary acquisition theories and the concepts is a prerequisite in designing the vocabulary aspects of an English language textbook and teaching vocabulary to a set of second language learners of the language. This study also stands as a vindication to Schmitt's (2000) assumption that "...exposure to language and practice with functional communication..." along with "...a principled selection of vocabulary... according to frequency lists and an instructional methodology that encourages meaningful engagement with words over a number of recylings," (p. 14) could prove to be the best practice to ensure adequate vocabulary learning. By means of explicit instruction and repeated exposure to the target vocabulary the receptive and the productive knowledge of vocabulary can be increased manifold. Recent studies (Masruddin, 2019; Pamintuan et al., 2018) showed beneficial aspects of adding Spell Bee game sessions and using networking applications like WeChat in improving students' vocabulary acquisition in foreign language. The researcher- created supplementary can be used for teaching the prescribed vocabulary in the target group under similar conditions with few such effective additions.

This study has provided a new dimension in defining the nature of the receptive- productive gap. It can be understood from the statistical data analysis that the receptive- productive gap is dynamic and that they are influenced to a very large extent by the mode of vocabulary instruction and teaching materials. The study highlights the various issues concerned with the traditional mode of vocabulary instruction and provides implications to the teachers and the curriculum designers of the State Council for Educational Research and Training (SCERT) Board.

The pretest that was conducted to equate the samples from the controlled and the experimental groups was designed for the prescribed vocabulary from the previous academic year (fifth Standard Term III) English textbook. While evaluating the test sheets, the researcher observed that the students scored well only in Level 3 (see Table 1), where they were asked to choose the right meaning of a particular word out of the three given options. The meanings provided in the test were exactly the same as the meanings provided in their textbook. The students barely got any of the answers right in the fourth or the fifth 
levels and surprisingly neither claimed to know the word in the first and second two levels of vocabulary knowledge. This showed that the students had merely memorized the meanings of the words from their last term for their exams without actually understanding what the words meant. This pattern of vocabulary learning was later empirically proved in the regression analysis which showed that in the conventional mode of vocabulary instruction, the reception of vocabulary had an average of only $8 \%$ influence on the production ability of vocabulary. It is stated that in the traditional way of vocabulary teaching the students merely attain only the 'partial-recognition' phase of vocabulary knowledge in terms of the defined stages of vocabulary knowledge development proposed by Henriksen's (1999).

\section{Ethics Committee Approval}

The author(s) confirm(s) that the study does not need ethics committee approval according to the research integrity rules in their country (Date of Confirmation: December 11, 2020).

\section{References}

Henriksen, B. (1999). Three dimensions of vocabulary development. Studies in Second Language Acquisition, 21(2), 303-317.

Joe, A. (2010). The quality and frequency of encounters with vocabulary in English for academic purposes program. Reading in a Foreign Language, 22(1), 117- 138.

Laufer, B. \& Nation. I. S. P. (1999). A vocabulary size test of controlled productive ability. Language Testing, 16, 33- 51.

Liang, H. (2019). (Book Review) Expand your English: A guide to improving your academic vocabulary by Steve Hart. Asian EFL Journal, 23(6.1), 142-143.

Masruddin. (2019). The efficacy of using spelling bee game in teaching vocabulary to Indonesian English as a Foreign Language students. Asian EFL Journal, 23(6.3), 173-180.

Meara, P. (1997). Towards a new approach to modelling vocabulary acquisition. In N. Schmitt \& M. McCarthy (Eds.), Vocabulary: Description, acquisition and pedagogy (pp. 109- 121). Cambridge, UK: Cambridge University Press.

Melka, F. (1997). Receptive vs. productive aspects of vocabulary. In N. Schmitt \& M. McCarthy (Eds.), Vocabulary: Description, acquisition and pedagogy (pp.82- 102). Cambridge, UK: Cambridge University Press.

Nagy, W. (1997). On the role of context in first- and second- language vocabulary learning. In N. Schmitt \& M. McCarthy (Eds.), Vocabulary: Description, acquisition and pedagogy (pp. 64- 83). Cambridge, UK: Cambridge University Press.

Nation, I. S. P. (2001). Learning vocabulary in another language. Cambridge, UK: Cambridge University Press.

O'Dell, F. (1997). Incorporating vocabulary into the syllabus. In N. Schmitt \& M. McCarthy (Eds.), Vocabulary: Description, acquisition and pedagogy (pp. 258- 278). Cambridge, UK: Cambridge University Press.

Palmberg, R. (1987). Patterns of vocabulary development in foreign language learners. Studies in Second Language Acquisition, 9, 201- 220. 
Pamintuan, C.F., Mallari, D. G., Garcia, N. T., Galang, J. P., Buduan, R. M. (2018). The use of WeChat application on CFL learners' vocabulary acquisition. TESOL International Journal, 13(4), 26-38.

Richards, J. C. (1976). The role of vocabulary teaching. TESOL Quarterly, 10(1), 77-89.

Schmitt, N. (2000). Vocabulary in language teaching. Cambridge: Cambridge University Press.

State Council of Educational Research and Training. (2017). TNCF 2017 Draft Syllabus English Language. Retrieved from http://tnscert.org/webapp2/tn17syllabus.aspx?language=LG$1 \&$ status $=$ Active

Thornbury, S. (2006). How to teach vocabulary. Pearson Education India.

Waring, R. (1999). Tasks for assessing second language receptive and productive vocabulary (Unpublished Doctoral dissertation). University of Wales, Cardiff.

Wesche, M. and T. Paribakht. (1996). Assessing vocabulary knowledge: depth vs. breadth. Canadian Modern Language Review, 53(1), 13-40.

\section{Appendix A. Components of the supplementary (in reference to Section 4)}

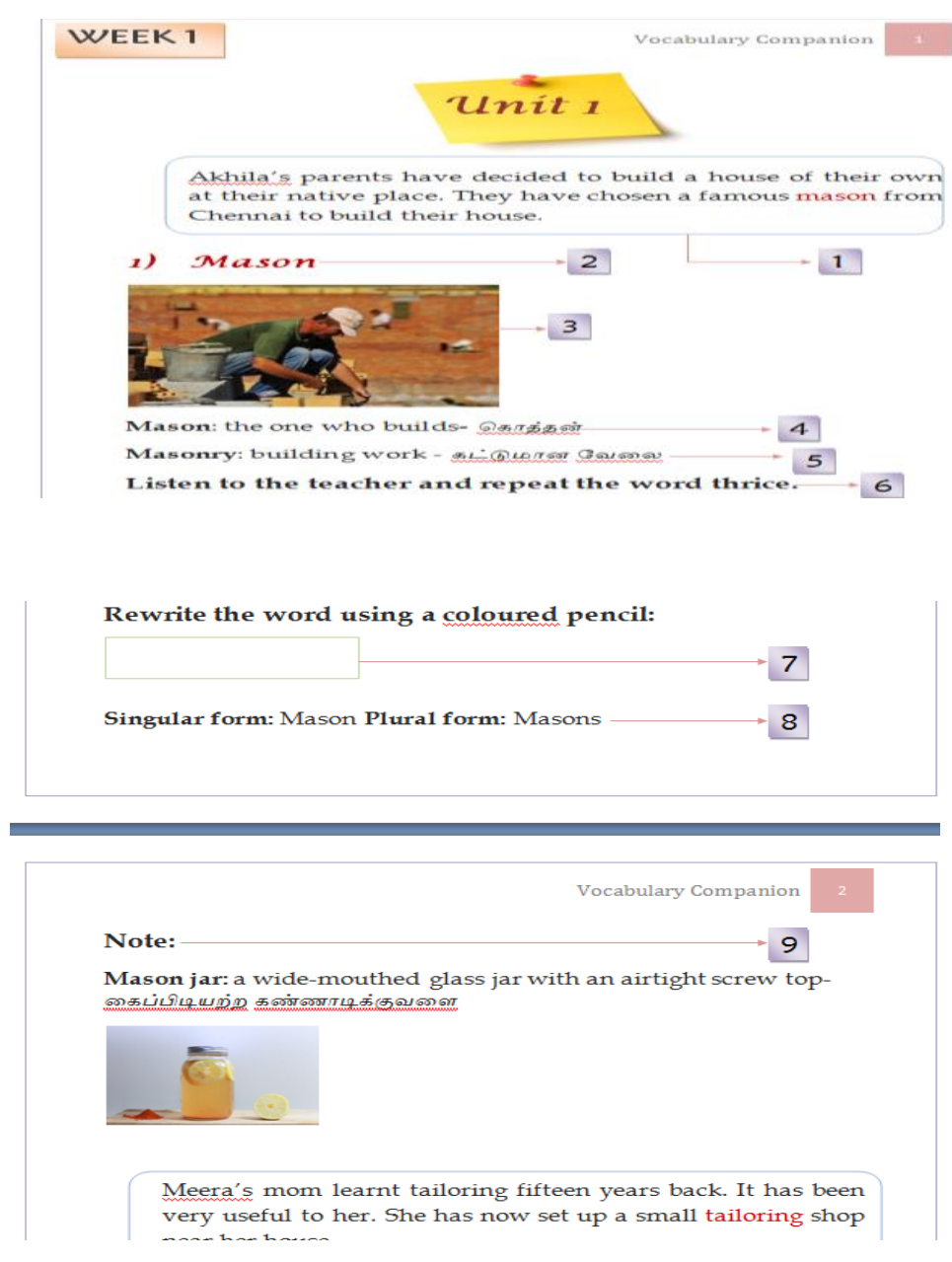




\section{Appendix B. Snapshot of the VI ${ }^{\text {th }}$ STD English language textbook (Unit 1- Prose 1- Sea Turtles)}

\section{Section II}

Take turns and read this section aloud. Work in pairs and underline the new words. Find out their meanings from the dictionary.

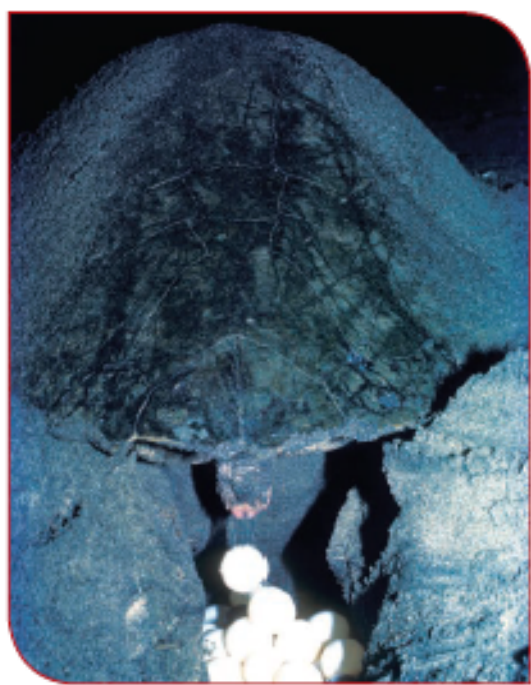

Olive Ridley laying eggs

Between the months of January and March, female Olive Ridleys come ashore at night to lay their eggs. This is quite a problem for them, as a turtle's front flippers enable it to swim gracefully and effortlessly but are not very useful for moving on land. The turtle has to haul itself laboriously onto the beach. Then it chooses a spot well away from the high-tide line. Here, it scoops out a nest cavity $45 \mathrm{~cm}$ deep, into which it lays about 100 eggs. Each egg is in the shape and size of a table tennis ball. Once all the eggs are laid, the turtle fills in the cavity, then it camouflages the nest by tossing sand on it using its flippers. That done, it returns to the sea. The eggs are left to incubate under the warmth of the sun.

In many places around the world, local people follow the tracks of the turtle to its nest. They collect the eggs for eating. Jackals, domestic dogs and pigs too dig up and eat the eggs by following the scent left by the turtle. Those eggs that escape such people and predators hatch 45-60 days later. The hatchlings slash open the leathery eggshell with the help of a tiny 'egg-tooth'. This is like a razor blade at the tip of a hatchling's snout. When most of the eggs have hatched, the hatchlings push themselves upwards through the sand and emerge on the surface of the beach. From here they make a hurried dash to the sea.

\section{GLOSSARY}

$\begin{array}{ll}\text { flippers } & \text { - broad, flat limbs used for swimming } \\ \text { predators } & \text { - animals that kill other animals for food } \\ \text { haul } & \text { - pull with force } \\ \text { slash } & \text { - cut } \\ \text { laboriously } & \text { - with great effort }\end{array}$

flippers - broad, flat limbs used for swimming

slash - cut

laboriously - with great effort

snout $\quad$ - pointed nose of an animal
cavity $\quad$ - a hollow space
emerge $\quad$ - come out
camouflage - hide or disguise something
incubate - hatch eggs using warmth

90 


\section{Appendix C. Snapshots of the vocabulary supplementary}

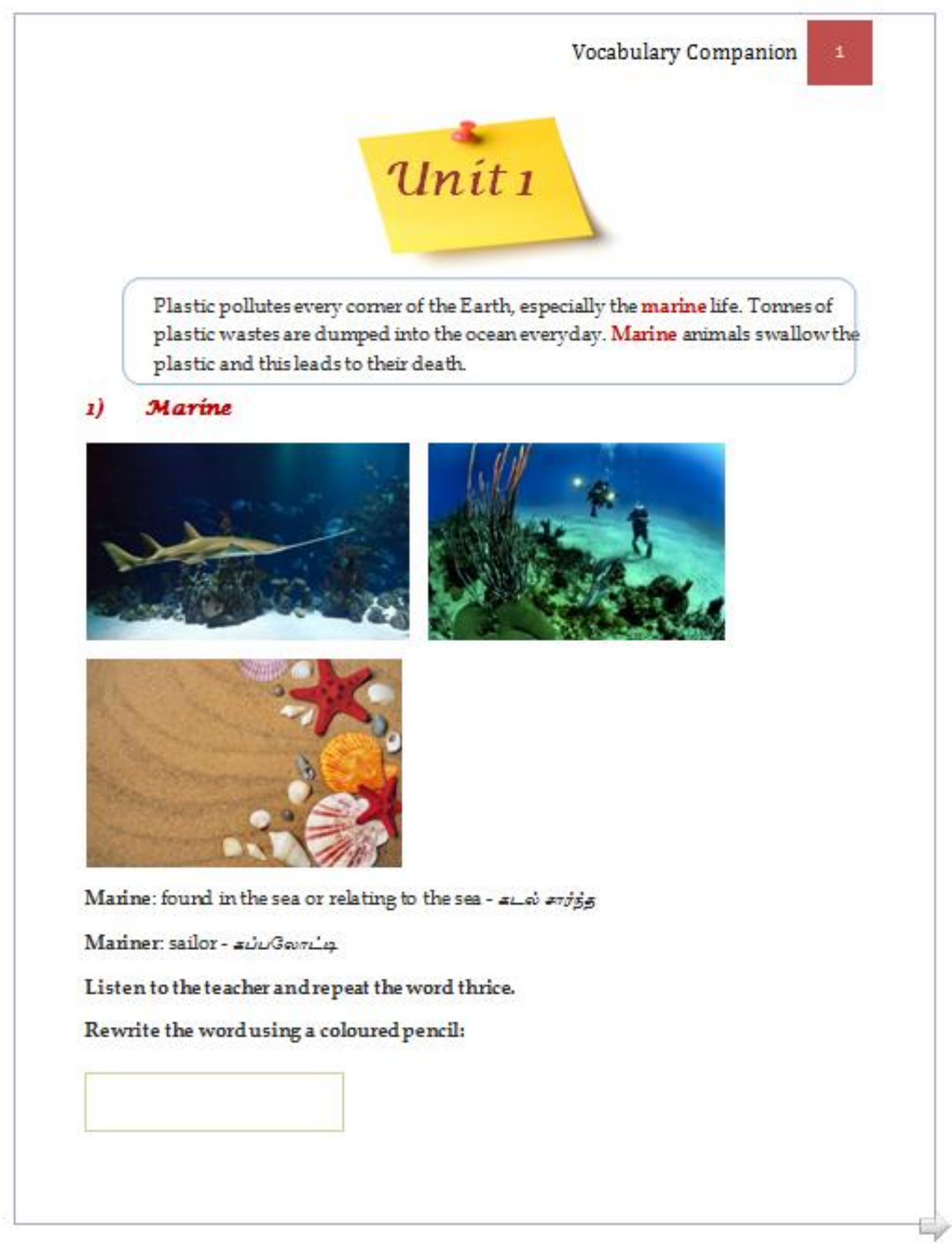




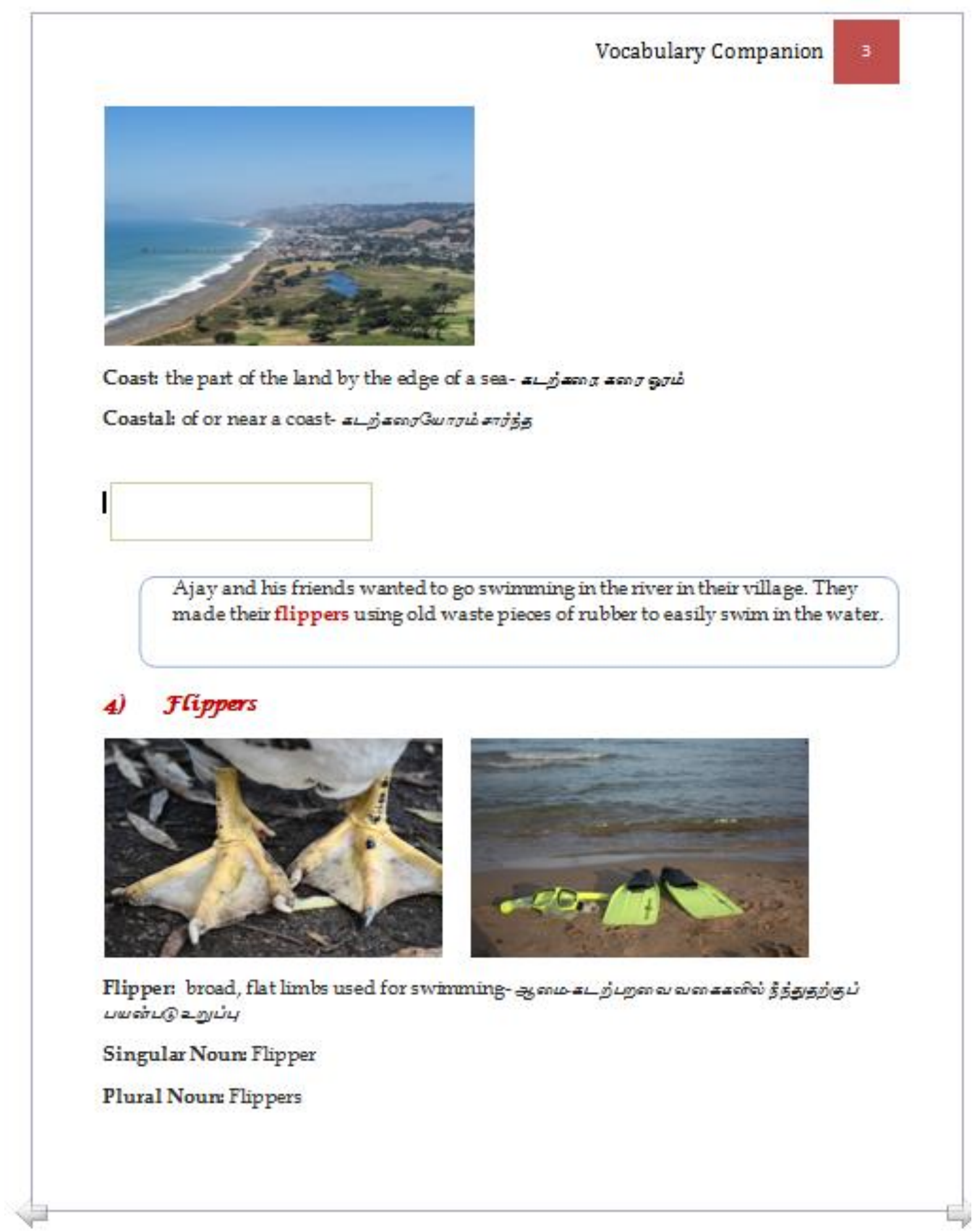


Sharks are the only predators of dolphins. Dolphins form small groups of twelve or more and use this as a way to protect themselves from their predator.

\section{5) Predators}
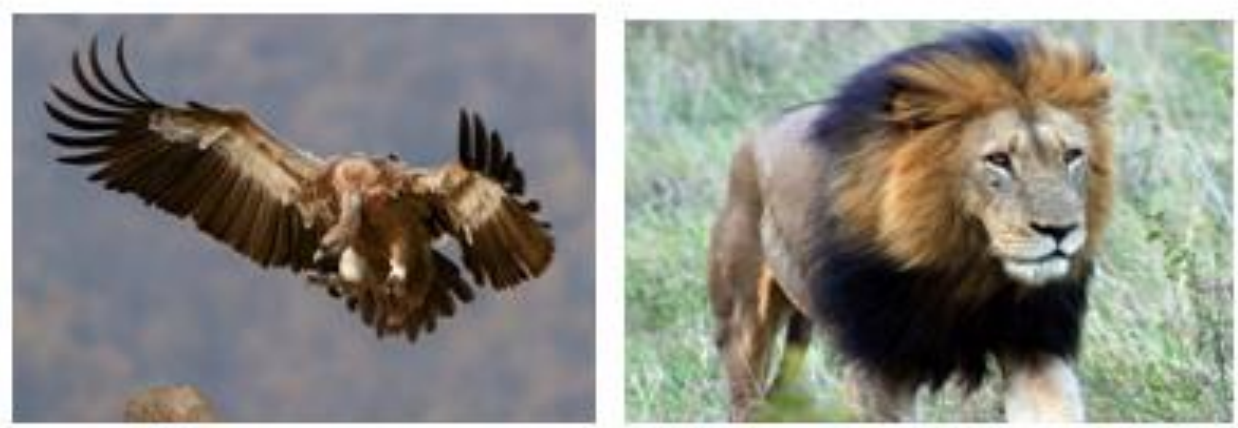

Predator animals that kill other animals for food- வी ลن่ Qx migy

\section{Singular Noun: Predator}

Plural Noun: Predators

Anita went to Ooty with her family during the summer holidays. When they were climbing on the hilly roads their car suddenly stopped. Their car was then hauled up to the service center.

\section{6) Haul}




\section{Açık öğretimin kelime öğrenimi ve alıcı-üretken boşluk üzerindeki etkisinin incelenmesi: Deneysel bir çalışma}

\section{$\ddot{\mathbf{O z}}$}

$\mathrm{Bu}$ araştırma, İngilizce'yi ikinci dil olarak öğrenenler arasında yeni kelimelerin etkili bir şekilde alınması ve üretilmesi için hedef kelime dağarcı̆̆ına açık öğretimin ve tekrar tekrar maruz kalmanın önemini vurguladı. Çalışmanın amacı, İngilizce ders kitabında öngörülen kelime dağarcığı seti için araştırmacı tarafından oluşturulan tamamlayıcı maddenin etkinliğini incelemekti. Çalışma, açık öğretim ve hedef kelime dağarcığına tekrar tekrar maruz kalmanın alıcı-üretken boşluğun doğası üzerindeki etkisini bulmayı amaçladı. Üç aylık bir süre boyunca yürütülen deneysel araştırmaya Hindistan Tamil Nadu'daki bir Devlet okulundan toplam altmış iki altıncı sınıf öğrencisi katıldı. Çalışmanın sonuçları, açık öğretim ve hedef kelime dağarcığına tekrar tekrar maruz kalmanın, geleneksel kelime öğretimi yöntemine kıyasla kelime bilgisi üzerinde önemli bir etkiye sahip olduğunu göstermiştir. Geleneksel kelime öğretimi biçiminde, kelime almanın üretim bilgisi üzerinde ortalama\% 8 etkiye sahip olduğu, deney grubu durumunda ise\% 72'ye kadar çıktığı bulunmuştur. Bu analiz, açık öğretim ve hedef kelime dağarcığına tekrar tekrar maruz kalma yoluyla alıcı-üretken boşluğun önemli ölçüde azaldığını göstermiştir.

Anahtar sözcükler: açık talimat; tekrarlayan maruziyet; alıcı kelime hazinesi; üretken kelime dağarcığı; alıcıüretken boşluk

\section{AUTHOR BIODATA}

Infanta Vincy R is currently pursuing her PhD in English at Christ (Deemed to be University), Bangalore, India. She is researching on English language education policy planning in India and is developing learning materials and oral assessment model as part of her PhD research study. Her M Phil dissertation was on bridging the gap between reception and production of vocabulary development among the second language learners from South India. She received her BA degree from Bharathiar University and MA degree from Christ (Deemed to be) University. Her research interests are second language vocabulary instruction, English language education policy planning and materials development. 